A

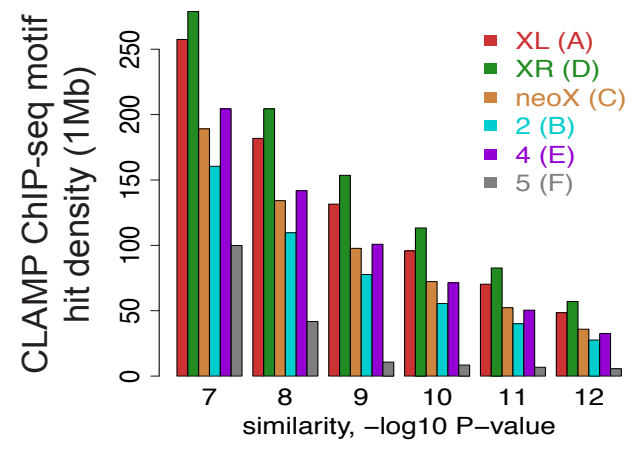

B

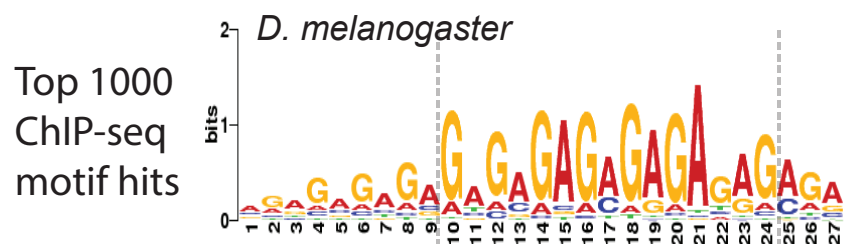

Custom PBM

motif hits

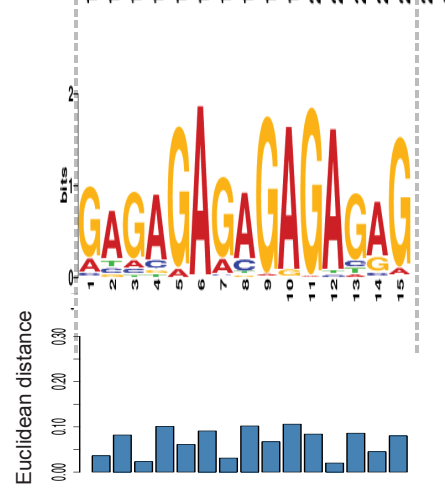

\title{
C Occurence of motifs
}
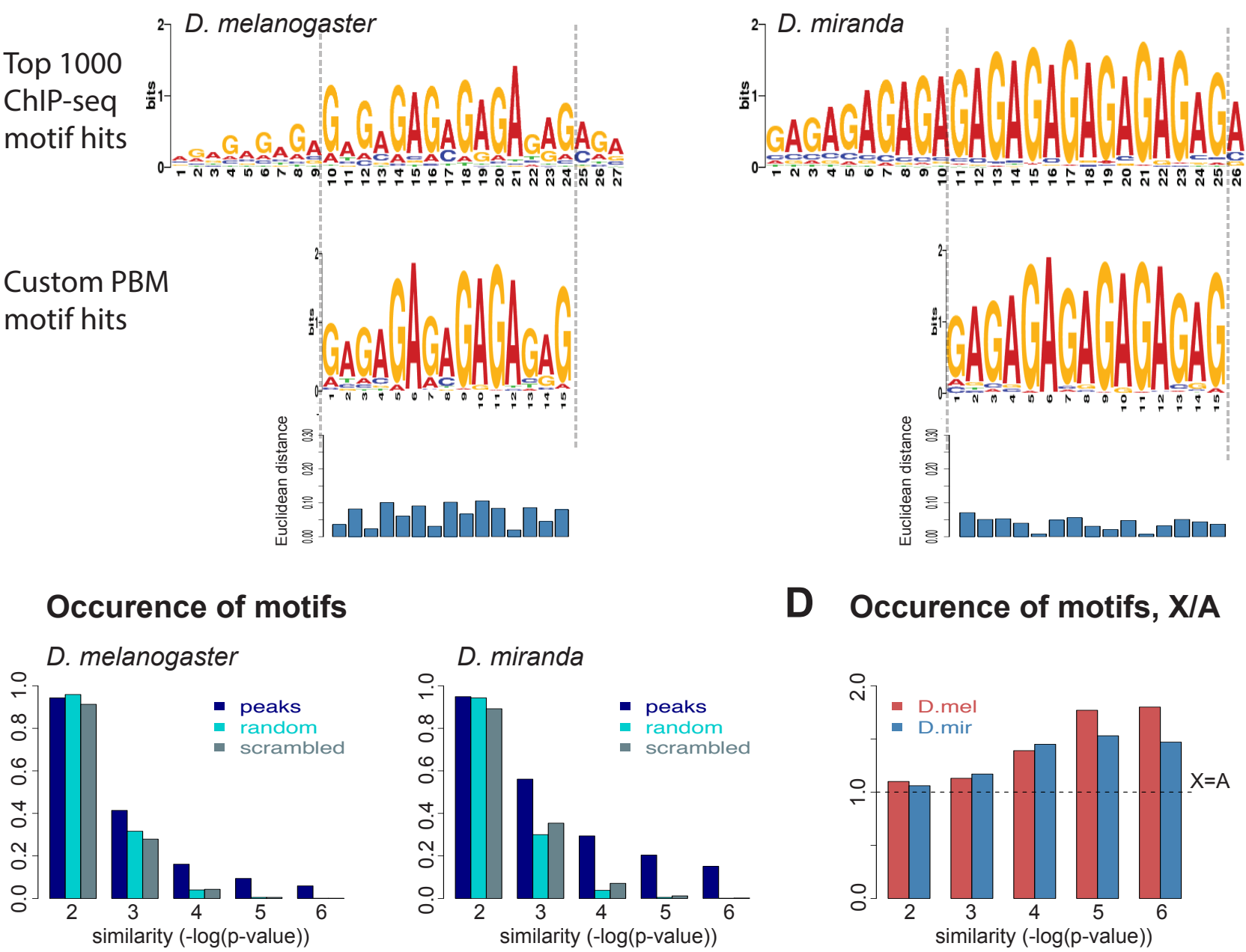

D Occurence of motifs, X/A

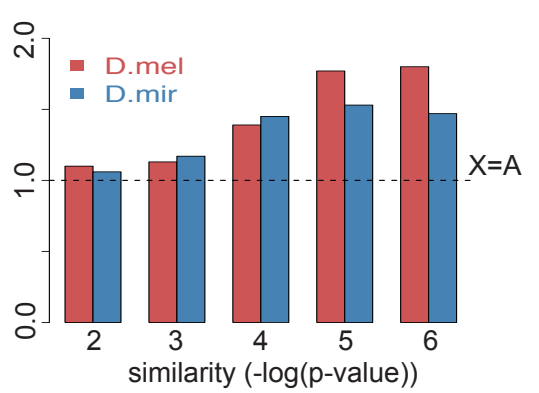

